Editorial

\title{
New Perspectives on the II CIAM onwards: How Does Housing Build Cities?
}

\author{
Alessandro Porotto and Chiara Monterumisi * \\ Laboratoire de Construction et Conservation, Faculté de L’Environnement Naturel, Architectural et Construit, École \\ Polytechnique Fédérale de Lausanne, 1015 Lausanne, Switzerland; E-Mails: alessandro.porotto@epfl.ch (A.P.), \\ chiara.monterumisi@epfl.ch (C.M.) \\ * Corresponding author
}

Submitted: 26 August 2019 | Published: 30 September 2019

\begin{abstract}
Far from nostalgically celebrate the 90th anniversary of the second CIAM, which indeed opened in October 1929 in Frankfurt, the present issue is intended as collective work, a springboard which aims to widen the debate over housing experiences beyond geographical and temporal frameworks. The focus of that event, the Existenzminimum, has often been cited as representing a fundamental contribution to the rational design of the modern dwelling. But the debates during that event went beyond the definition of this concept, because demonstrated, on the one hand, how the responsibility of architects would imply the resolution of multiple technical aspects, starting from the typological concern stretching towards the town planning aspects, and on the other hand, the calling to develop a multifaceted intellectual vision of society. Though the title selected for the present issue, namely 'Housing Builds Cities', denotes the different scales of the project, the aim is to achieve a something more. First and foremost, the objective is not strictly confined to a historical understanding of facts around the 1929 congress. Today a critically objective approach is useful to examine past contributions and, if applicable, their actualization. Secondly, this special issue intends to address the CIAMs' theoretical and architectural legacy. The hypothesis on their interpretation suggests that these are still topical issues today. The issue comprises fourteen articles which investigate, through different applied methodologies, the years from the first steps of the CIAMs to the 1929 aftermath, analyze the post-war production and explore many case-studies, of which some are also geographically far from a Euro-centric vision as well as contemporary realities.
\end{abstract}

\section{Keywords}

CIAM; city; dwelling typology; Existenzminimum; housing; morphology; social responsibility; urban policy

\section{Issue}

This editorial is part of the issue "Housing Builds Cities", edited by Luca Ortelli (École Polytechnique Fédérale de Lausanne, Switzerland), Chiara Monterumisi (École Polytechnique Fédérale de Lausanne, Switzerland) and Alessandro Porotto (École Polytechnique Fédérale de Lausanne, Switzerland).

(C) 2019 by the authors; licensee Cogitatio (Lisbon, Portugal). This article is licensed under a Creative Commons Attribution 4.0 International License (CC BY).

\section{Introduction}

Beyond the Bauhaus centenary, 2019 also marks 90 years since the second Congrès International d'Architecture Moderne (CIAM) held in Frankfurt in October 1929. At first glance, dedicating an issue of Urban Planning to this anniversary today, could appear as merely a nostalgic operation. The focus of that event, the Existenzminimum, has often been cited as a fundamental contribution to the rational design of the modern dwelling. However, this concept is still strongly tied to the architectural experiments of the 1920s-1930s. The nostalgic view then disappears altogether if the II CIAM is dissected from two further viewpoints.

Firstly, the Frankfurt congress globally attracted the largest interest in the housing debate and studies of the ensuing decades. Since the end of the 1950s, and principally throughout the 1960s, a young group of Italian architects employed examples of modern architecture, using mainly those conceived in the 1920 s when the mass 
housing buildings gained momentum. The understanding of urban studies would have lacked critical strength from an analytical and operative viewpoint without the brilliant commentaries of a group internationally known in the 1970s as Tendenza: Aldo Rossi (1966) on the Siedlungen, Carlo Aymonino (1965) on the development of European modern cities and Giorgio Grassi (1967) on the dwelling conception in Germany. It was not by chance that Aymonino was the first one to acknowledge the intrinsic value of the II CIAM. Beside the translation of the proceedings book released for the II (Frankfurt, 1929) and III CIAM (Brussels, 1930) conferences, his publication (1971) compares the multiple perspectives of the participants with some significant European housing experiences. Apart from the account of the I CIAM held in La Sarraz by Jacques Gubler (1975) in his extensive book dealing with the Swiss venture of modernity, Martin Steinmann (1979) offers a thorough picture of the 1928-1939 modern congresses. For the first time, he analyses and compares the congresses preparatory texts as well as those published.

The return to the centre stage of the CIAMs has been fostered by Eric Mumford (2002), whose account not only exhaustively reconstructs all the events until the last one in 1959, but primarily examines the debate around new ideas and their reception in detail. In addition, the proceedings book of the international symposium Neues Wohnen 1929/2009: Frankfurt und der 2. Congrès International d'Architecture Modern (Barr, 2011) celebrating the 80th anniversary of the II CIAM also provides fresh critical perspectives contributed by researchers who look at the multiple aspects of the congress. This summary shows how the interest in the CIAMs, particularly the one held in Frankfurt, has always been addressed towards a historical reconstruction of the events as well as a detailed exploration into the topics at the centre of the debate. The actualization (if applicable) of the Existenzminimum is the goal of the next 5th Bernardo Secchi working seminar held at the École Polytechnique Fédérale de Lausanne almost contemporaneously to the release of this thematic issue (for more information visit https://www.braillard.ch/fr/ecocentury/journees-bernardo-secchi/existenzminimum-90ans-2e-ciam). Under the title Existenzminimum: 90 Years Since the 2nd CIAM, the organizers Paola Viganò, Panos Mantziaras and Christine Lutringer aim to foster the debate on the 100-year-long path of the norms that rule the urban condition.

The second reason which goes beyond any nostalgia developed in this issue of Urban Planning derives directly from the programmatic text of Ernst May-a central figure of the congresses as well as promoter of the Frankfurt housing accomplishments-published in the catalogue of the exhibition Die Wohnung für das Existenzminimum:

The most important part of the problem in fact is how to construct, in every detail and thoroughly, the indi- vidual dwelling cell. Apart from this task...architects have to solve the problem...how to incorporate the total of those cells, that is the neighbourhood, into the general aspect of the town in a way which will create equally favourable conditions to every section of inhabitants. (May, 1930, pp. 6-7)

The clarity and commitment in addressing the housing question here, is remarkable. The responsibility of architects implies of course the resolution of multiple technical aspects, but this also calls them to develop a multifaceted intellectual vision of society today and in the future. Taking cues from these words, Aymonino (1971) formulates one of the more brilliant definitions of the Existenzminimum, combining the anaIytical/cognitive aspect of urban phenomena, the practical/operative contribution of the design and then an observation of social conditions. "The implied meaning of 'minimum' in the concept of Existenzminimum corresponds generally to 'civic' or, anyway, necessary conditions not so much for the survival as for a social life" (Aymonino, 1971, p. 81, authors' translation), particularly regarding the lower classes of society. This refers not only to the reduced size of the dwelling, because already in the 19th and 20th centuries the speculators and developers built thousands of dwellings of considerably reduced size, making a profit to the dramatic detriment of sanitary conditions. Hence, the real value of the minimum dwelling needs to relate to the number of bedrooms and beds, which satisfy the layout of family or social group. Aymonino discusses that the Existenzminimum aims of relating the minimum individual surface (the dwelling) to the minimum social space (the city): "many beds form a dwelling, many dwellings form a typological unit, many typological units form a settlement, many settlements 'are' the city" (Aymonino, 1971, p. 82, authors' translation).

"Housing Builds Cities", the title of this issue of Urban Planning, has been formulated from this standpoint. Though this title denotes the different scales of the project, this issue aims to achieve something more. First and foremost, the objective is not strictly confined to a historical understanding of facts around the 1929 congress. Today a critically objective approach is useful to examine past contributions and if applicable, their actualization. Secondly, this thematic issue intends to address the CIAMs' theoretical and architectural legacy. The hypothesis on their interpretation suggests that these are still topical issues today.

\section{Contents}

The present issue comprises fourteen articles which investigate the years from the first steps of the CIAMs to the 1929 aftermath, analyse the post-war production and explore many case-studies, of which some are also geographically far from an Euro-centric vision as well as contemporary realities. 


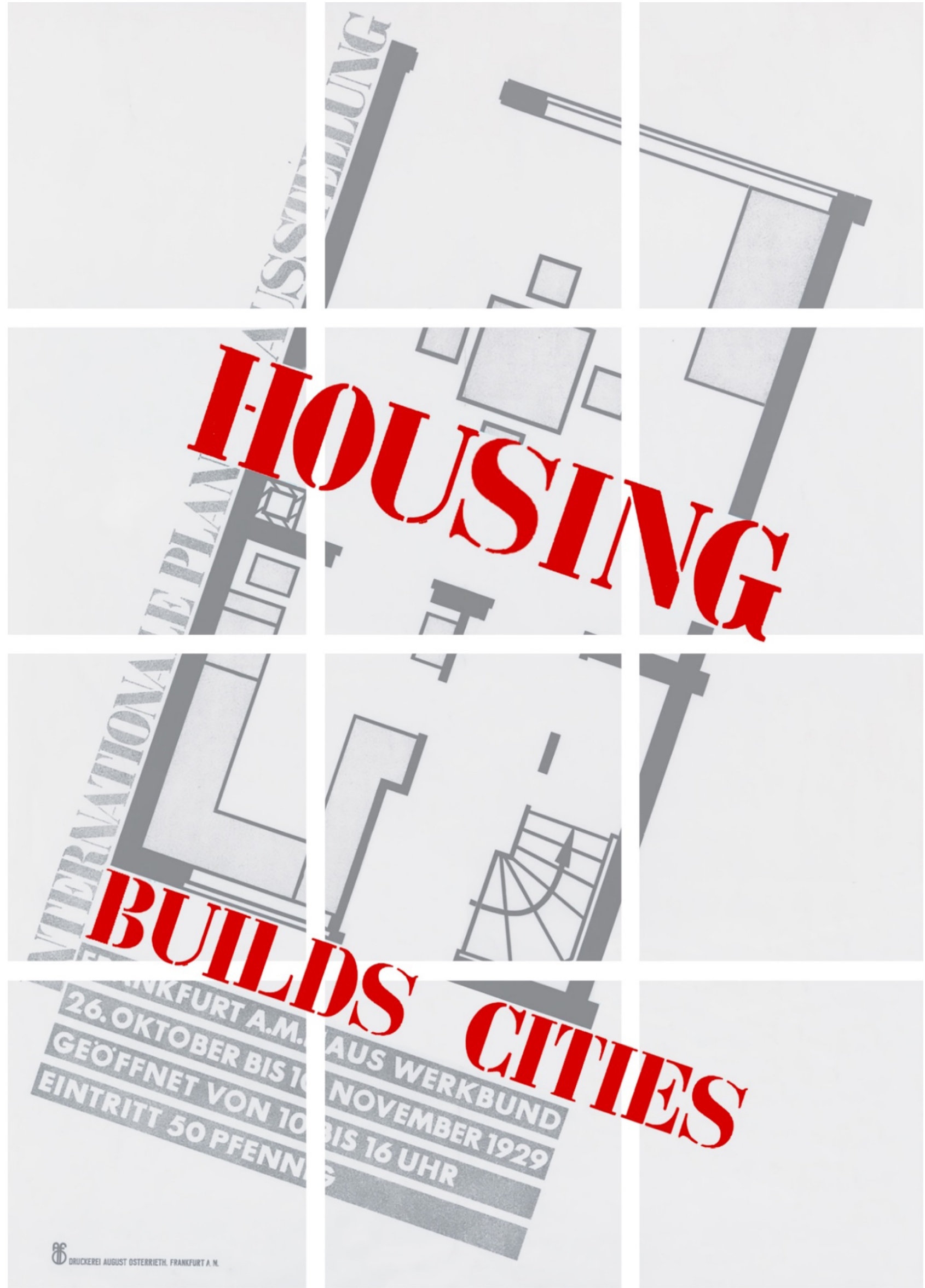

Figure 1. Graphic elaboration produced by the LCC starting from the poster of the exhibition Die Wohnung für Das Existenzminimum. 
The rich variety of the fourteen articles demonstrates how-historical, social and cultural transformations notwithstanding-housing has always embodied a "social, morphological and structural unit for living" (Bauer, 1934, p. 15) which has affected, and continues to affect, the form and evolution of the city. The thematic arrangement in three macro-groups has not been done according to geographical or applied methodologies subdivisions. This tripartite structure implicitly sums up all the components of the title "Housing Builds Cities".

Part I is opened by Paola Viganò (2019), who explores the multiple developments and spatial formulations which tackled the project of the industrial modern city in terms of social and urban transformations. The group of authors analyse the complexity of the urban scales which the housing interventions were designed for and how these engage in a spatial dialogue with the city.

Susanne Komossa and Martin Aarts (2019) provide a thorough and temporally extended picture of the CIAMs multifaceted legacy in the evolution of Dutch urbanism. The typo-morphological method applied by the authors comprises the Italian perspective developed by Muratori and the French School of Jean Castex and Philippe Panerai. This effective approach pinpoints the continuity of certain key features as well as the innovations of some others throughout the ensuing years of stimulating debates spurred by some Dutch figures who gained global significance. The set of crucial residential interventions in Amsterdam and Rotterdam chosen between the timespan of 1920-1980 aims to investigate both the typological and morphological aspects, likewise, of understanding the future scenarios for urban expansion of the two cities.

Of the panorama of urban theory, the contribution of the group Lidwine Spoormans, Daniel Navas-Carrillo, Hielkje Zijlstra and Teresa Pérez-Cano (2019) focuses on a particular track when new spatial formulations at global scale, namely the New Towns, occupied the architectural debate from the 1960s onwards, questioning the interwar CIAM's principles of envisaging the city. The attention is oriented to the Dutch framework where substantial experiments were carried out with such configurations. The examination of the planning policies, spatial strategies and typological configurations behind the development of Lelystad right up to the present, is hence instrumental for understanding the overall Dutch interaction between the search for an ideal shape and the impact of political top-down decisions in the construction of New Towns.

Silvia Malcovati (2019) addresses a pivotal issue of the contemporary debate over planning the European city, particularly within the German context. For achieving such a purpose, the author presents two housing projects built in Frankfurt whose spatial models illustrate two extreme city planning conceptions. Against the low-density satellite neighbourhood model promoted by Ernst May and substantially built in the outskirts for low-income people, the author discusses the urban regeneration built with traditional techniques and lan- guage for the Dom-Römer area housing upper-middleclass, designed 90 years later. The comparative analysis from a morphological and typological point of view between Das Neue Frankfurt (the modernist side of the 1920s-1930s) and Das Alte Frankfurt-as the author wittily labelled the latter-entails an opposition between Siedlungsbau and Städtebau as well as Trabantenstadt and Stadtquartier. A thorough and broad contextualization of theoretical references and methodologies provide the necessary instruments to pinpoint analogies and differences within the case-studies.

Andreina Milan (2019) turns the spotlight on the German urbanist and designer Wilhelm Riphahn and his prolific interventions-a neglected side of his production-designed for the active GAG building and management cooperative of social housing in Cologne at the beginning of the 20th century. For the first time, the article examines some case-studies via significant archival items and contextualises these projects into the wider coeval framework of other projects in the same regard. Of particular interest is the peculiar Riphahn design development. Here the key concept 'city of short distances', as promoted by the housing cooperative, is characterized by reduced dimensions and a strong sense of identity of the new 'urban settlers'.

Hamed Khosravi (2019) sheds new light on two significant exponents of the Iranian theoretical and practicing housing debate: the secretary of I CIAM and well-recognized avant-garde figure Gabriel Guevrekian, who paved the way for ensuing major developments in Teheran fostered by the driving force of the Association of Iranian Architects; then Silvio Macetti (known as Noureddin Kianouri), whose contribution clearly illustrates the application and modification of the CIAM discourse in shaping the post-war neighborhoods and housing typologies in Teheran. Within a framework of social and political changes, their initiatives reformulated the concept of domesticity, the living unit and household, showing a real engagement which led towards the Middle East's first modern metropolis.

Yael Allweil and Noa Zemer (2019) offer a novel reading into Patrick Geddes's remarkable Tel Aviv modern urban plan (1925), particularly focusing on a less-explored aspect of his contribution. This fresh standpoint sees Geddes' work as a radical bottom-up plan in which the housing question and community of dwellers are cornerstones and the main motivators for the spatial configurations based on self-constructing of semi-autonomous urban blocks in a 'housing before street' development. New archival findings and a revised study of available sources underpin the article's arguments. Besides the historical contextualization and exploration of the source of references, the author investigates the real architectural qualities and adopted principles in the workers' neighborhoods in detail.

Part II initiates with the commentary of Bruno Marchand (2019), who examines certain key concerns of the conceptualization and design of the minimum 
dwelling starting from the congress in Frankfurt till today's projects. The authors in this second part offer a wide range, though not complete, of case studies which comprises different ways of envisaging and, then, designing the typological unit, that is the dwelling.

Gérald Ledent (2019) dissects the Belgian modernist production and thinking around urban scale and housing configurations through the long-lasting experience of the key figure of Victor Bourgeois. The significance of his output is clearly visible in the development of Brussels since the III CIAM (actually held there) until the numerous euphoric post-war interventions. Of particular interest is the objective comparative method through which the author illustrates the case-studies; from a historical framework, he comprises ideas and principles to a typomorphological analysis delivered by novel drawings and archival items aiming to stress analogies and differences in the (heroic) pre- and (pragmatic) post-war period. This thorough approach indeed goes beyond any ideological prejudices and then efficiently fills the gap between the ideals of modernism and its implementation.

Rhea Rieben (2019) explores the pioneering Eglisee residential colony for low-income groups in Basel, designed in accordance with the II CIAM arguments for typification, rationalization and standardization. Despite such promising premises, the different housing prototypes of thirteen Swiss avant-garde studio firms-fully equipped with pieces of furniture conceived as an expression of the new living needs-did not achieve the same international resonance as the Neubühl intervention in Zurich, vigorously promoted by Sigfried Giedion. From a such neglected corner, the author intends to contribute fresh knowledge about this example built for the Woba exhibition in 1930, focusing mainly on Hans Schmidt and Paul Artaria's outputs. A thorough examination of the Swiss press coverage demonstrates the contested reception of this project, as if this reaction reflected the increasingly fractured state of society itself.

Nicola Braghieri (2019) delves into the Hungarianborn Ernő Goldfinger's conception of the high-rise building for accommodating the masses since his first engagement at the IV CIAM onwards, with a particular focus on two iconic residential towers of the London townscapethe Balfron and Trellick Towers built in the 1960s-1970s. Assuming a non-functionalist realist and objective architectural approach, Braghieri's goal is to overturn some preconceptions formulated about the failure of public urban policies in the United Kingdom, where large complexes, especially the towers, are considered an inhuman form. Though in recent years these two buildings (sadly) encountered difficulties in compensating the extreme marginality of their location on the outskirts, the author convincingly demonstrates how Goldfinger's experiments in reducing the density through vertical construction and in emphasizing the technical and social aspects deserve further attention.

Nelson Mota (2019) discusses the particular relevance of Alvaro Siza's approach in tackling citizens' par- ticipation in the design decision-making for the project Punt en Komma in The Hague. His previous experience for the SAAL program here became decisive for a further development of a precise line of action featuring a fruitful dialogue between experts, inhabitants and stakeholders. The urban renewal of the area is achieved by a convincing negotiated code, the two sides teamed up in an efficient way, in order to re-connect housing policies to their social significance. Of the 1970s-1980s urban renewal projects executed through this design process, Punt en Komma constitutes a successful example, as the article thoughtfully explores through Siza archives and a systematic architectural analysis, as well as useful references for creating conditions of social sustainability and inclusion.

Manlio Michieletto, Adedayo Olatunde and Victor Muka Bay (2019) assert certain spatial analogies between the satellite city model promoted by Ernst May and two recent housing interventions, Kigali 2020 and Kigali Vision, in Rwanda. The transfer of such principles from Frankfurt to East Africa was driven by May himself during his almost twenty-year stay there, where he designed many housing complexes. Beside the historical reconstruction of May's design experience in Africa, the authors offer an intriguing typo-morphological analysis of how this spatial model was re-interpreted in the two satellite housing settlements 60 years later. These projects clearly illustrate how the future planning visions for the city of Kigali aim to rationalise the proliferation of informal settlements, especially via a dialogue between the landscape and development of the city.

Part III is introduced by a commentary from Eric Mumford (2019), who thoughtfully draws analogies and differences into the thought-provoking debates underpinned by the CIAMs long-lasting experience and how these ideas widely influenced planning and architectural production. Starting from the legacy of the CIAMs, the authors in this third part provide new theoretical perspectives and methodological approaches which ask if some key II CIAM topics could be actualized in housing design and debate today.

Andrea Migotto and Marson Korbi (2019) go beyond the mere historiographic comparison of the II CIAM and III CIAM official (but multiple) standpoints with those spurred by two remarkable conference participantsAlexander Klein and Karel Teige. Their alternative theories, pioneering social studies and design experimentations, based on life and movement abstraction through the application of Taylorism principles, led to further investigations carried out convincingly by the authors. Since the post-War technocratic approach pursued rationalization to create ready-made solutions for universal users, the authors assert that Klein and Teige's pragmatic method is a still valid, almost emancipating, tool for tackling the qualities of today's minimum affordable dwelling vis-à-vis the evolving relationship between households and the social-economic structure.

Valentin Bourdon (2019) ambitiously traces the transformations of the notion of 'urban homogeneity' and its 
translation in architectural terms through four periods in France; the Haussmannian celebration of the bourgeois, the modern enthusiasm crystallized in the II CIAM, the trauma of the masses identified in the grand ensembles built from the 1960s and the future scenarios of nondifferentiation. A selection of Parisian case-studies belonging to the four stages supports the core of the critical standpoint which assumes homogeneity both as result of the progressive densification of the city, but paradoxically it would also become a significant spatial formalization of 'living-together'.

Sara Brysch (2019) aims to explore a practically unbeaten side of the Existenzminimum concept. She asks what its current reception is, which design principles are absorbed, and which are hybridized in some selected cases of contemporary (re)interpretation(s) of this topical issue. A review of viewpoints, methods and outcomes of the II CIAM set the parameters that guided the development of the concept from an architectural perspective. The author analyzed today's case-studies including their diverse spatial configurations, dwelling typologies and geographical context, using a framework of three different architectural dimensions, namely technical, spatial and social.

Beside the multifaceted perspectives presented by the fourteen contributions, the fourth and last part of the thematic issue draws the attention to another kind of output come out from research studies: this is the case of the exhibition 'HOUSING Frankfurt Wien Stockholm' curated by LCC Lab and held at the EPFL, that demonstrated the multiple variations in designing and building the cities.

\section{Conclusions}

Looking at the variety of the fourteen contributions and the structure of this thematic issue, it is fair to note that no uniform understanding is possible and it is difficult to compare the iconography used in each article. Reaching the uniformity of the publication characterizing Die Wohnung für das Existenzminimum has not been the goal of the present issue, therefore the exceptional nature of the 1929 event comes across even more strongly. However, the multiplicity of articles points to our hypothesis: The topics discussed 90 years ago and in the ensuing CIAMs arise again today in new guises, or perhaps they have not yet received a definitive answer.

The issue is not intended as a finished work, rather, as Gubler (1975) observed for the CIAM held in Frankfurt, as collective work, a springboard which aims to widen the debate over housing experiences beyond geographical and temporal frameworks.

\section{Conflict of Interests}

The authors declare there are no conflicts of interests.

\section{References}

Allweil, Y., \& Zemer, N. (2019). Housing-based urban planning? Sir Patrick Geddes' modern masterplan for Tel Aviv, 1925. Urban Planning, 4(3), 167-185.

Aymonino, C. (1965). Origini e sviluppo della città moderna [Origins and development of the modern city]. Padova: Marsilio.

Aymonino, C. (1971). L'abitazione razionale. Atti dei congressi C.I.A.M. 1929-1930 [The rational dwelling. Proceedings of the 1929-1930 CIAM congresses]. Padova: Marsilio.

Barr, H. (2011). Neues Wohnen 1929/2009: Frankfurt und der 2. Congrès International d'Architecture Moderne [Modern living 1929/2009: Frankfurt and the 2nd International Congress of Modern Architecture]. Berlin: Jovis.

Bauer, C. (1934). Modern housing. Cambridge: Riverside Press.

Bourdon, V. (2019). Does the homogeneous city belong to the past? Urban Planning, 4(3), 315-325.

Braghieri, N. (2019). 'The towers of terror': A critical analysis of Ernő Goldfinger's Balfron and Trellick towers. Urban Planning, 4(3), 223-249.

Brysch, S. (2019). Reinterpreting Existenzminimum in contemporary affordable housing solutions. Urban Planning, 4(3), 326-345.

Grassi, G. (1967). La costruzione logica dell'architettura [The logical construction of architecture]. Padua: Marsilio.

Gubler, J. (1975). Nationalisme et internationalisme dans l'architecture de la Suisse [Nationalism and internationalism in the Swiss architecture]. Lausanne: Ed. l'Age d'Homme.

Khosravi, H. (2019). CIAM goes east: The inception of Tehran's typical housing unit. Urban Planning, 4(3), 154-166.

Komossa, S., \& Aarts, M. (2019). The legacy of CIAM in the Netherlands: Continuity and innovation in Dutch housing design. Urban Planning, 4(3), 90-101.

Korbi, M., \& Migotto, A. (2019). between rationalization and political project: The Existenzminimum from Klein and Teige to today. Urban Planning, 4(3), 299-314.

Ledent, G. (2019). From ideal proposals to serial developments: Victor Bourgeois's schemes in the light of post-war developments in Brussels. Urban Planning, $4(3), 196-211$.

Malcovati, S. (2019). Das Alte Frankfurt: Urban neighborhood versus housing estate, the rebirth of urban architecture. Urban Planning, 4(3), 117-133.

Marchand, B. (2019). Moving on: Is Existenzminimum still relevant? Urban Planning, 4(3), 186-195.

May, E. (1930). Die Wohnung für das Existenzminimum [The minimum subsistence dwelling]. In Die Wohnung für das Existenzminimum: Einhundert Grundrisse met erklärenden Referaten von Victor Bourgeois, Le Corbusier unf Pierre Jeanneret, Sigfried 
Giedion, Walter Gropius, Ernst May und Hans Schmidt [The minimum subsistence dwelling: One hundred floor plans with explanatory lectures by Victor Bourgeois, Le Corbusier and Pierre Jeanneret, Sigfried Giedion, Walter Gropius, Ernst May and Hans Schmidt] (first page-last page). Frankfurt am Main: Englert \& Schlosser.

Michieletto, M., Olatunde, A., \& Bay, V. (2019). African housing renaissance ensuring favorable conditions for all inhabitants: The case of Gacuriro Valley satellite settlements Kigali, Rwanda. Urban Planning, 4(3), 265-190.

Milan, A. (2019). Wilhelm Riphahn in Cologne (19131963): Urban policies and social housing between innovation and conservation. Urban Planning, 4(3), 134-153.

Mota, N. (2019). Álvaro siza's negotiated code: Meaningful communication and citizens' participation in the urban renewal of the Hague (Netherlands) in the 1980s. Urban Planning, 4(3), 250-264.
Mumford, E. (2002). The CIAM discourse on urbanism 1928-1960. Cambridge, MA: MIT Press.

Mumford, E. (2019). CIAM and its outcomes. Urban Planning, 4(3), 291-298.

Rieben, R. (2019). Contested architecture: The 'Woba' residential colony in Basel, 1930. Urban Planning, 4(3), 212-222.

Rossi, A. (1966). L'architettura della città [The architecture of the city]. Padua: Marsilio.

Spoormans, L., Navas-Carrillo, D., Zijlstra, H., \& PérezCano, T. (2019). Planning history of a Dutch new town: Analysing Lelystad through its residential neighbourhoods. Urban Planning, 4(3), 102-116.

Steinmann, M. (1979). CIAM Internationale Kongresse für Neues Bauen: Dokumente 1928-1939 [The international CIAMs' congresses for the Neues Bauen: Documents 1928-1939]. Basel: Birkhäuser.

Viganò, P. (2019). The modern project: A research hypothesis. Urban Planning, 4(3), 83-89.

\section{About the Authors}
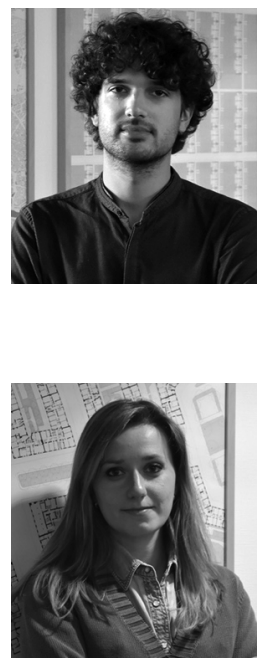

Alessandro Porotto is an Architect and Post-Doc Research Scientist at the École Polytechnique Fédérale de Lausanne. At the Laboratory of Construction and Conservation he conducts studies on housing and urban topics, and on German architect Heinrich Tessenow. In 2018, he obtained his PhD degree at the École Polytechnique Fédérale de Lausanne defending the dissertation Logement de masse: Vienne et Francfort (Mass Housing: Vienna and Frankfurt). The research project was fully funded by the Swiss National Science Foundation. The publication of his dissertation, entitled L'intelligence des formes (Intelligence of Forms), is planned by November 2019 with the support of an SNSF grant for open access publications.

Chiara Monterumisi is an Architect and Post-Doc Research Scientist at the École Polytechnique Fédérale de Lausanne. At the Laboratory of Construction and Conservation, she conducted the Post-Doc project Stockholm: Housing in the Interwar Period granted by the Swiss National Science Foundation (2016-2018). She obtained her PhD degree in 2015 at the Università di Bologna (Italy) in co-tuition with KTH-Kungliga Tekniska Högskolan (Stockholm), defending the thesis Ragnar Östberg. Genius loci and Urban Memories. In 2017, supported by the C. M. Lerici Stiftelsen i Stockholm, she published the book Ragnar Östberg. Villa Geber: una casa nell'arcipelago (Ragnar Östberg. Villa Geber: A House in the Archipelago), which recasts the twofold focus of her PhD dissertation by analysing in much more details the domestic project. 